\title{
HUBUNGAN GAYA KEPEMIMPINAN DEMOKRATIS DENGAN KINERJA PERAWAT DALAM PENATALAKSANAAN STANDAR PRAKTIK PROFESSIONAL DI RUANG MAWAR MERAH KELAS II RSUD ASEMBAGUS KABUPATEN SITUBONDO
}

\author{
Yulianto $^{1^{*}}$, Nasrul Hadi Purwanto ${ }^{1}$, Ricco Risky Firmansyah ${ }^{1}$ \\ ${ }^{1}$ STIKES Dian Husada Mojokerto \\ *Correspondence: \\ Yulianto \\ Email: yulisiiip@gmail.com
}

\begin{abstract}
Background: Kunci utama dalam peningkatan kualitas pelayanan kesehatan adalah petugas yang mempunyai kinerja tinggi. Kinerja menjadi tolak ukur keberhasilan pelayanan kesehatan yang menunjukkan akuntabilitas lembaga pelayanan dalam kerangka tata pemerintahan yang baik. Sehingga bila kinerja petugas baik maka kualitas pelayanan yang akan diberikan akan baik pula.

Purpose: Tujuan penelitian ini adalah untuk mengetahui hubungan gaya kepemimpinan demokratis kepala ruang dengan kinerja perawat dalam penatalaksanaan standar praktik professional di ruang mawar merah kelas II RSUD Asembagus Kab. Situbondo.

Method: Desain penelitian ini menggunakan cross sectional. Populasi dalam penelitian ini adalah perawat di ruang mawar merah kelas II RSUD Asembagus Kab. Situbondo. Sampel yang diambil sebanyak 20 orang responden. Metode sampling yang digunakan adalah NonProbability Sampling tipe Sampling Jenuh. Data penelitian ini diambil dengan menggunakan kuesioner dan observasi. Setelah ditabulasi data yang ada dianalisis dengan menggunakan uji spearman correlation dengan tingkat kemaknaan 0,05.

Results: Hasil penelitian menunjukkan gaya kepemimpinan demokratis kepala ruang dengan kategori gaya kepemimpinan demokratis perilaku baik sebanyak 13 responden $(65 \%)$ dan kinerja perawat pelaksana dengan kinerja baik sebanyak 8 responden (40\%). Ada hubungan antara gaya kepemimpinan demokratis kepala ruang dengan kinerja perawat pelaksana dalam penatalaksanaan standar praktik professional di ruang mawar merah kelas II RSUD Asembagus Kab. Situbondo dengan koefisiensi kolerasi sebesar -525 dengan tingkat signifikan $0,018(\rho<0,05)$.

Conclusion: Upaya untuk meningkatkan kinerja perawat pelaksana dengan cara mengadakan pelatihan dan seminar kesehatan yang lengkap, mendorong untuk berinisiatif dan kreatif dalam melaksanakan tugas, menetapkan target pencapaian yang layak dan jelas. Dengan gaya kepemimpinan demokratis kepala ruang yang baik dapat meningkatkan kinerja perawat pelaksana dalam pelayanan kesehatan dan akan berdampak pada kepuasan pasien.
\end{abstract}

Key words: Gaya kepemimpinan demokratis, kinerja perawat, standar praktik profesional

\section{PENDAHULUAN}

Perawat dan rumah sakit merupakan dua hal yang tidak bisa dipisahkan. Perawat memegang peran utama dalam menjalankan roda kehidupan pada pelayanan rumah sakit. Apabila perawat memiliki produktivitas dan motivasi kerja yang tinggi, maka laju roda pun akan berjalan baik, yang akhirnya akan menghasilkan kinerja dan pencapaian yang baik bagi rumah sakit. Di sisi lain, roda tidak akan berjalan baik kalau perawat 
bekerja tidak produktif, arinya perawat tidak memeiliki semangat kerja yang tinggi, tidak ulet dalam bekerja dan memiliki moril yang rendah (Depkes RI, 2004). Gambaran kinerja dalam penatalaksanaan kegiatan merupakan seperangkat fungsi tugas dan tanggung jawab. Masalah utama kinerja perawat dalam memberikan standar asuhan keperawatan adalah kurangnya perawat yang berpendidikan tinggi, kemampuan yang tidak memadai, banyaknya perawat yang kasar (kurang ramah terhadap pasien), kurang sabar dalam menghadapi pasien. Masalahya bukan hanya itu saja melainkan soal sikap ramah atau penyabar, tetapi juga beban kinerja yang tinggi, peraturan yang belum jelas kepada perawat (Aditama, 2003). Banyak beberapa keluhan yang diungkapkan dari pasien terutama di RSUD Asembagus Kabupaten Situbondo terhadap kinerja perawat yang kurang baik seperti kurangnya respon perawat dan sikap yang kurang bersahabat dalam pelayanan. Kinerja tidak baik juga diungkapkan oleh pimpinan ruangan bahwa kurangnya disiplin kerja terhadap jam kehadiran yang rata-rata terlambat, dan rasa tanggung jawab kerja yang rendah serta tidak adanya keinginan untuk maju dalam kerja oleh perawat menjadi salah satu faktor permasalahan dalam kualitas kerja.

Menurut penelitian yang dilakukan J. Thomson (2012) di amerika dari 10 rumah sakit yang terdiri dari 43 kepala ruangan didapatkan $60 \%$ penampilam karyawan dapat dipengaruhi oleh motivasi, tidak pernah ada titik nol atau tingkat tertinggi dalam kinerja karyawan. Berdasarkan hasil studi pendahuluan di RSUD Asembagus tanggal 23 bulan November 2016 melakukan wawancara dengan 5 perawat pelaksana menyebutkan bahwa selama ini mereka melaksanakan kinerja dalam standar praktik professional sesuai dengan kebiasannya, mereka melaksanakan pengkajian pada saat klien masuk ruangan dan melengkapi format catatan pengkajian, tetapi 3 diantaranya kurang dalam melaksanakan standar asuhan keperawatan karena perawat tidak sesuai melakukan rencana keperawatan berdasarkan kebutuhan klien dan juga perawat kurang sesuai ntuk melakukan evaluasi praktik keperawatan, dalam melakukan standar praktik professional karena sesuai melakukan rencana keperawatan berdasarkan kebutuhan klien dan juga sesuai dalam mengevaluasi praktik keperawatan. Hasil wawancara dengan 6 pasien, 3 diantaranya pasien mengatakan kurang puas terhadap pelayanan keperawatan yang kurang tanggap terhadap keluhan klien, 1 pasien mengatakan cukup dan 2 pasien mengatakan puas terhadap kinerja perawat di RSUD Asembagus Kabupaten Situbondo

Ada beberapa hal diduga berperan dalam peningkatan kinerja perawat antara lain, adanya hadiah sarana yang mendukung, gaya kepemimpinan, motivasi dan disiplin kerja. Terdapat faktor negatif yang dapat menurunkan kinerja karyawan, diantaranya adalah menurunnya keinginan karyawan untuk mencapai prestasi kerja, kurangnya ketepatan waktu dalam penyelesaian pekerjaan sehingga kurang menaati peraturan, pengaruh yang berasal dari lingkungannya, teman sekerja yang juga menurun semangatnya dan tidak adanya contoh yang harus dijadikan acuan dalam pencapaian prestasi kerja yang baik. Semua itu merupakan sebab menurunnya kinerja perawat dalam bekerja. Gaya kepemimpinan yang tepat akan menimbulkan motivasi seseorang untuk 
berprestasi. Sukses tidaknya dalam prestasi kerja dapat dipengaruhi oleh gaya kepemimpinan atasannya (Hardini, 2001 dalam suranta, 2012).

Kepemimpinan adalah kemampuan untuk mempengaruhi orang lain untuk mencapai tujuan upaya yang harus dilakukan agar memiliki gaya kepemimpinan yang efektif dan perawat mengikuti pelatihan, seminar, dan studi banding pada pelayanan kesehatan yang lain, sehingga mutu pelayanan rumah sakit dapat meningkat sesuai kinerja yang di harapkan. Berdasarkan masalah diatas tersebut maka peneliti tertarik melakukan penelitian gaya kepemimpinan terhadap kinerja perawat di ruang mawar merah kelas II RSUD Asembagus Kabupaten Situbondo.

\section{METODE DAN BAHAN}

Jenis penelitian ini menggunakan metode analitic dengan pendekatan cross sectional dimana penelitian yang bertujuan menemukan ada tidaknya hubungan antara dua variabel (gaya kepemimpinan demokratis dengan kinerja perawat dalam penatalaksanaan standar praktik professional di ruang mawar merah kelas II RSUD Asembagus). Pendekatan Cross Sectional, adalah rancangan penelitian dengan melakukan pengukuran atau pengamatan observasi data gaya kepemimpinan dengan kinerja perawat hanya diobservasi satu kali dan pengukuran dilakukan satu kali.

Populasi dalam penelitian gaya kepemimpinan demokratis dengan kinerja perawat adalah seluruh perawat yang bekerja di Ruang Mawar Merah kelas II (20 Perawat) di RSUD Asembagus Kabupaten Situbondo dengan total berjumlah 20 responden. Penelitian dilakukan pada responden perawat yang bukan menjabat kepala ruangan, yang setuju dilakukan penelitian dengan menandatangani surat persetujuan, yang hadir pada saat penelitian. Sampel berjumlah 20 responden dengan pemilihan sampel menggunakan teknik sampling jenuh.

Penelitian pada variabel gaya kepemimpinan demokratismenggunakan kuisioner peryataan berbentuk scala likert yang berjumlah Terdiri dari 18 pernyataan favourable dan unfavourable, 9 favourable (pernyataan mendukung) dan 9 unfavourable (pernyataan tidak mendukung) dengan alternatif jawabannya menggunakan skala likert yaitu dengan menggunakan pilihan jawaban: Sangat setuju (SS), setuju (S), ragu (R), tidak setuju (TS), dan sangat tidak setuju (STS).Ketentuan untuk pernyataan favourable interpretasi penilaiannyaSangat setuju (SS) skor 5, setuju (S) skor 4, Netral/Ragu (N) skor 3, tidak setuju (TS) skor 2, dan sangat tidak setuju (STS) skor 1 dan sebaliknya untuk pernyataan unfavourableSangat setuju (SS) skor 1, setuju (S) skor 2, ragu (R) skor 3, tidak setuju (TS) skor 4, dan sangat tidak setuju (STS) skor 5. Sedangkan untuk variabel kinerja perawat menggunakan observasi dengan scale likert dalam sebuah pernyataan yang berjumlah 25 item menggunakan jawaban: Tidak pernah dilaksanakan (TPD): 1, Kadang-kadang dilaksanakan (KKD): 2, Sebagian dilaksanakan (SBD): $3, \quad$ Sering dilaksanakan (SRD): $\quad 4, \quad$ Selalu dilaksanakan (SLD): 5.

Hasil kuisioner gaya kepemimpinan demokratis dan kinerja yang sudah terkumpul diolah menggunakan rumus:

$$
\mathrm{N}=\frac{S p}{S m} X 100 \%
$$


Keterangan:

$\mathrm{N} \quad$ : Nilai yang didapat

Sp : Skor yang didapat

Sm : Skor yang diharapkan

Sehingga ditemukan presentase gaya kepemimpinan demokratis yang dirumuskan kedalam tiga kategori, yaitu:

Baik 76-100\%; Cukup 56-75\%; Kurang $\leq$ $55 \%$ (Sugiono 2010). Untuk variabel kinerja perawat dilakukan dengan menggunakan skoring. Karakteristik skoring untuk kinerja perawat, antara lain: Tidak pernah dilaksanakan $(\mathrm{TPD})=1$; Kadang-kadang dilaksanakan $(\mathrm{KKD})=2$; Sebagian dilaksanakan $(\mathrm{SBD})=3$; Sering dilaksanakan $(\mathrm{SRD})=4$; Selalu dilaksanakan $(\mathrm{SLD})=5$ (Notoatmodjo, S., 2012).

Analisis data untuk mengidentifikasi hubungan gaya kepemimpinan demokratis dengan kinerja perawat mengunakan uji korelasi spearman rank dengan $\alpha=0,05$ dan tingkat kepercayaan $95 \%$ signifikan atau bermakna, apabila $\rho$ value $=<\alpha$ maka $\mathrm{H} 0$ ditolak dan $\mathrm{H} 1$ diterima, artinya ada hubungan antara gaya kepemimpinan demokratis kepala ruang dengan kinerja perawat dalam standar praktik professional di ruang mawar merah kelas II RSUD Asembagus Kab. Situbondo.

\section{HASIL PENELITIAN}

\section{Karakteristik Responden Berdasarkan} Jenis Kelamin.

Tabel 1. Karakteristik responden berdasarkan jenis kelamin di Ruang Mawar Merah kelas II di RSUD Asembagus Kab. Situbondo.

\begin{tabular}{|c|c|c|c|}
\hline No & Jenis kelamin & Jumlah & $\begin{array}{c}\text { Persen } \\
(\boldsymbol{\%})\end{array}$ \\
\hline 1 & Laki-laki & 7 & $35 \%$ \\
\hline 2 & Perempuan & 13 & $65 \%$ \\
\hline \multicolumn{2}{|c|}{ Total } & $\mathbf{2 0}$ & $\mathbf{1 0 0 \%}$ \\
\hline
\end{tabular}

Berdasarkan tabel 1 menunjukkan bahwa sebagian besar dari jumlah responden berjenis kelamin perempuan sebanyak 13 responden (65\%) dan hampir setengah yang berjenis kelamin laki-laki yaitu sebanyak 7 responden $(35 \%)$.

\section{Karakteristik Responden Berdasarkan Pendidikan.}

Tabel 2. Distribusi Frekuensi Responden Berdasarkan Pendidikan di Ruang Mawar Merah kelas II di RSUD Asembagus Kab. Situbondo.

\begin{tabular}{|c|c|c|c|}
\hline No & Riwayat & Jumlah & $\begin{array}{c}\text { Persen } \\
(\boldsymbol{\%})\end{array}$ \\
\hline 1 & D3 keperawatan & 17 & $85 \%$ \\
\hline 2 & S1 keperawatan & 3 & $15 \%$ \\
\hline \multicolumn{2}{|c|}{ Total } & $\mathbf{2 0}$ & $\mathbf{1 0 0 \%}$ \\
\hline
\end{tabular}

Berdasarkan tabel diatas menunjukkan bahwa hampir seluruhnya dari jumlah responden berpendidikan D3 keperawatan sebanyak 17 responden $(85 \%)$ dan sebagian kecil responden yang berpendidikan S1 keperawatan sebanyak 3 responnden $(15 \%)$.

\section{Karakteristik Responden Berdasarkan Umur.}

Tabel 3. Distribusi Frekuensi Responden Berdasarkan Umur di Ruang Mawar Merah kelas II di RSUD Asembagus Kab. Situbondo

\begin{tabular}{|c|c|c|c|}
\hline No & Umuur & Jumlah & $\begin{array}{c}\text { Persen } \\
(\boldsymbol{\%})\end{array}$ \\
\hline 1 & $20-30$ tahun & 11 & $55 \%$ \\
\hline 2 & $31-40$ tahun & 8 & $40 \%$ \\
\hline 3 & $41-50$ tahun & 1 & $5 \%$ \\
\hline 4 & $>50$ tahun & - & - \\
\hline \multicolumn{2}{|c|}{ Total } & $\mathbf{2 0}$ & $\mathbf{1 0 0 \%}$ \\
\hline
\end{tabular}

Berdasarkan tabel 3 diatas menunjukkan bahwa sebagian besar dari responden berusia 20-30 tahun yaitu 
sebanyak 11 responden (55\%) dan sebagian kecil responden berusia 41-50 tahun sebanyak 1 responden $(5 \%)$.

\section{Karakteristik Responden Berdasarkan Lama Kerja.}

Tabel 4. Distribusi Frekuensi Responden Berdasarkan Lama kerja perawat di Ruang Mawar Merah kelas II di RSUD Asembagus Kab. Situbondo.

\begin{tabular}{|c|c|c|c|}
\hline No & Lama kerja & Jumlah & $\begin{array}{c}\text { Persen } \\
(\mathbf{\%})\end{array}$ \\
\hline 1 & $1-5$ tahun & 8 & $40 \%$ \\
\hline 2 & $6-10$ tahun & 7 & $35 \%$ \\
\hline 3 & $>10$ tahun & 5 & $25 \%$ \\
\hline \multicolumn{2}{|l|}{ Total } & $\mathbf{2 0}$ & $\mathbf{1 0 0 \%}$ \\
\hline
\end{tabular}

Berdasarkan tabel 4 diatas menunjukkan bahwa hampir setengah dari jumlah responden lama kerja 1-5 tahun sebanyak 8 responden (40\%) dan sebagian kecil responden lama kerja $>10$ tahun sebanyak 5 responden (25\%).

\section{Gaya Kepemimpinan Demokratis di Ruang Mawar Merah Kelas II.}

Tabel 5. Gaya kepemimpinan Demokratis di Ruang Mawar Merah Kelas II RSUD Asembagus Kabupaten Situbondo.

\begin{tabular}{|c|c|c|c|}
\hline No & $\begin{array}{c}\text { Gaya } \\
\text { kepemimpinan } \\
\text { demokratis }\end{array}$ & jumlah & $\begin{array}{c}\text { Persen } \\
(\boldsymbol{\%})\end{array}$ \\
\hline 1 & Perilaku baik & 13 & $65 \%$ \\
\hline 2 & Perilaku cukup & 6 & $30 \%$ \\
\hline 3 & Perilaku kurang & 1 & $5 \%$ \\
\hline \multicolumn{2}{|c|}{ Total } & $\mathbf{2 0}$ & $\mathbf{1 0 0 \%}$ \\
\hline
\end{tabular}

Berdasarkan tabel 5 diatas menunjukkan bahwa sebagian besar responden menilai pemimpin atau kepala ruangan dengan perilaku baik sebanyak 13 responden (65\%) dan hampir setengah menilai pemimpin atau kepala ruangan dengan perilaku cukup sebanyak 6 responden $(30 \%)$.

\section{Kinerja Perawat di Ruang Mawar kelas} II RSUD Asembagus Kabupaten Situbondo.

Tabel 6. Kinerja Perawat di Ruang Mawar Kelas II RSUD Asembagus Kabupaten Situbondo.

\begin{tabular}{|c|c|c|c|}
\hline No & $\begin{array}{c}\text { Kinerja perawat } \\
\text { pelaksana }\end{array}$ & Jumlah & $\begin{array}{c}\text { Persen } \\
(\%)\end{array}$ \\
\hline 1 & Baik sekali & 6 & $30 \%$ \\
\hline 2 & Baik & 8 & $40 \%$ \\
\hline 3 & Cukup & 4 & $20 \%$ \\
\hline 4 & Kurang & 2 & $10 \%$ \\
\hline 5 & Kurang sekali & - & - \\
\hline \multicolumn{2}{|r|}{ Total } & 20 & $100 \%$ \\
\hline
\end{tabular}

Berdasarkan tabel 6 diatas menunjukkan bahwa hampir setengah dari responden mempunyai kinerja baik sebanyak $8(40 \%)$ dan sebagian kecil responden dengan kinerja kurangsebanyak $2(10 \%)$.

Hubungan Gaya Kepemimpinan Demokratis Dengan Kinerja Perawat Penatalaksaan Standar Praktik Professional di Ruang Mawar Merah Kelas II RSUD Asembagus Kabupaten Situbondo.

Tabel 7. Tabulasi Silang Gaya Kepemimpinan Demokratis Dengan Kinerja Perawat Penatalaksaan Standar Praktik Professional di Ruang Mawar Merah Kelas II RSUD Asembagus Kabupaten Situbondo.

\begin{tabular}{|c|c|c|c|c|c|c|}
\hline \multirow{2}{*}{$\begin{array}{c}\text { Gaya } \\
\text { kepemimpinan } \\
\text { demokratis }\end{array}$} & \multicolumn{5}{|c|}{ Kinerja } & \multirow[t]{2}{*}{ Total } \\
\hline & $\begin{array}{c}\text { Baik } \\
\text { Sekali } \\
\end{array}$ & Baik & Cukup & Kurang & $\begin{array}{c}\text { Kurang } \\
\text { sekali }\end{array}$ & \\
\hline Baik & $\begin{array}{c}0 \\
0 \% \\
\end{array}$ & $\begin{array}{c}7 \\
35 \% \\
\end{array}$ & $\begin{array}{c}4 \\
20 \% \\
\end{array}$ & $\begin{array}{c}2 \\
10 \% \\
\end{array}$ & $\begin{array}{c}0 \\
0 \% \\
\end{array}$ & $\begin{array}{c}13 \\
65 \% \\
\end{array}$ \\
\hline Cukup & $\begin{array}{c}6 \\
30 \% \\
\end{array}$ & $\begin{array}{c}0 \\
0 \% \\
\end{array}$ & $\begin{array}{c}0 \\
0 \% \\
\end{array}$ & $\begin{array}{c}0 \\
0 \% \\
\end{array}$ & $\begin{array}{c}0 \\
0 \% \\
\end{array}$ & $\begin{array}{c}6 \\
30 \% \\
\end{array}$ \\
\hline Kurang & $\begin{array}{c}0 \\
0 \% \\
\end{array}$ & $\begin{array}{c}1 \\
5 \% \\
\end{array}$ & $\begin{array}{c}0 \\
0 \% \\
\end{array}$ & $\begin{array}{c}0 \\
0 \% \\
\end{array}$ & $\begin{array}{c}0 \\
0 \%\end{array}$ & $\begin{array}{c}1 \\
5 \% \\
\end{array}$ \\
\hline Total & $\begin{array}{c}15 \\
30 \% \\
\end{array}$ & $\begin{array}{c}5 \\
40 \% \\
\end{array}$ & $\begin{array}{c}0 \\
20 \% \\
\end{array}$ & $\begin{array}{c}0 \\
10 \% \\
\end{array}$ & $\begin{array}{c}0 \\
0 \%\end{array}$ & $\begin{array}{c}20 \\
100 \% \\
\end{array}$ \\
\hline
\end{tabular}


Berdasarkan tabel 7 diatas menunjukkan bahwa hampir setengah responden dengan gaya kepemimpinan yang baik dan kinerja baik sebanyak 7 responden (35\%) dan sebagian kecil responden dengan gaya kepemimpinan kurang dan kinerja baik sebanyak 1 responden $(5 \%)$.

Tabel 8. Korelasi Gaya kepemimpinan Demokratis dengan Kinerja Perawat Dalam Penatalaksanaan Standar Praktik Professional di Ruang Mawar Kelas II RSUD Asembagus Kabupaten Situbondo.

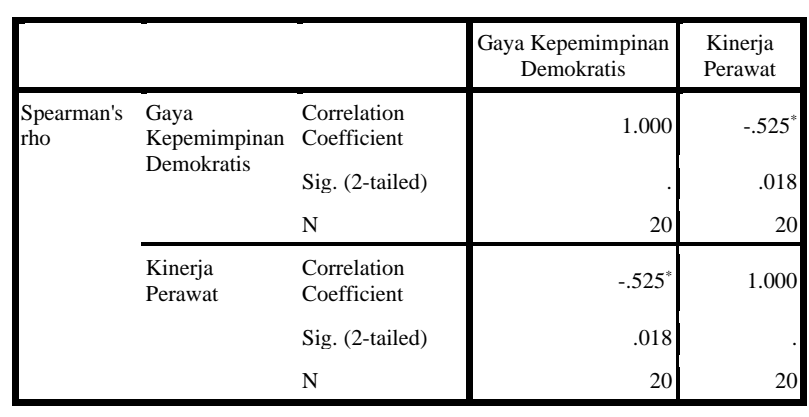

Berdasarkan tabel 8 diatas menunjukkan bahwa dari hasil analisa data hubungan gaya kepemimpinan demokratis kepala ruang dengan kinerja perawat pelaksana di RSUD Asembagus dengan menggunakan uji spearman rho diperoleh nilai $\rho$ Value $=0,018<\alpha$ yang berarti $\mathrm{H} 1$ diterima yang artinya ada hubungan Gaya Kepemimpinan demokratis dengan kinerja perawat di Ruang Mawar kelas II RSUD Asembagus dengan nilai korelasi Spearman sebesar -525 menunjukkan bahwa arah korelasi negatif dengan kekuatan korelasi yang lemah.

\section{PEMBAHASAN}

\section{Gaya Kepemimpinan Demokratis Kepala Ruang di Ruang Mawar Kelas II RSUD Asembagus Kab. Situbondo.}

Berdasarkan hasil analisa data gaya kepemimpinan demokratis kepala ruang sebagian besar responden menilai gaya kepemimpinan demokratis didapatkan bahwa gaya kepemimpinan demokratis kepala ruang sebagian besar responden menilai gaya kepemimpinan demokratis perilaku baik sebanyak 13 responden $(65 \%)$ dan hampir setengah responden menilai gaya kepemimpinan perilaku cukup sebanyak 6 responden (30\%) dari 20 responden. Dan yang menilai gaya kepemimpinan demokratis perilaku baik sebanyak 5 responden (25\%) berjenis kelamin laki-laki, 8 responden $(40 \%)$ berjenis kelamin perempuan, 12 responden (60\%) pendidikan D3 keperawatan, 1 responden $(5 \%)$ pendidikan S1 keperawatan, 8 responden $(40 \%)$ umur 20 30 tahun, 4 responden (20\%) umur 31-40 tahun, 1 responden $(5 \%)$ umur $>11$ tahun, 6 responden (30\%) lama kerja 1-5 tahun, 4 responden (20\%) lama kerja 6 -10 tahun, 3 responden $(15 \%)$ lama kerja $>10$ tahun. Dan yang menilai gaya kepemimpinan demokratis perilaku cukup sebanyak 2 responden $(10 \%)$ berjenis kelamin lakilaki, 4 responden $(20 \%)$ berjenis kelamin perempuan, 1 responden (5\%) pendidikan S1 keperawatan, 5 responden (25\%) pendidikan D3 keperawatan, 2 responden (10\%) umur 20-30 tahun, 4 responden (20\%) umur 31-40 tahun, 1 responden $(5 \%)$ lama kerja 1-5 tahun, 3 responden (15\%) lama kerja 6 - 10 tahun, 2 responden (10\%) lama kerja > 11 tahun.

Gaya Kepemimpinan Demokratis, yaitu gaya seorang pemimpin yang menghargai karakteristik dan kemampuan yang dimiliki oleh setiap anggota organisasi (Prima, A, 2013). Pemimpin selalu melibatkan bawahan dalam pengambilan keputusan saat ada masalah. Selain itu pimpinan juga memberikan gambaran dan bimbingan yang efisien 
tentang tugas yang akan diberikan kepadabawahannya. Lebih dari itu seorang pemimpin yang mempunyai gaya kepemimpinan demokratis akan menggunakan jabatan dan kekuatan pribadinya untuk memaksimalkan potensi yang ada pada bawahannya sehinga baik karyawan maupun perusahaan dapat berkembang bersama-sama. Pada gaya kepemimpinan demokratis ini terdapat koordinasi yang kuat atas pekerjaan yang diemban masing-masing bawahan sehingga kekuatan utama bukan pada pimpinan melainkan partisipasi aktif dari semua anggota. Rasa tanggung jawab internal pada masing-masing bawahan juga menjadi salah satu dasar dalam gaya kepemimpinan ini. Selain melibatkan bawahan dalam pengambilan keputusan, seorang pemimpin yang menerapkan gaya kepemimpinan ini juga harus bersedia mengakui keahlian para spesialis dengan bidangnya masingmasing. Juga mampu memanfaatkan kapasitas setiap anggota seefektif mungkin pada saat-saat dan kondisi yang tepat (Sasongko, F, 2014).

Gaya kepemimpinan demokratis kepala ruang yang diterapkan di ruang Mawar kelas II RSUD Asembagus Kab. Situbondo sangat berpengaruh terhadap kinerja perawat pelaksana dalam penatalaksanaan standar praktek professional di ruang mawar kelas II menilai gaya kepemimpinan demokratis kepala ruang perilaku baik dan cukup dan tidak ada yang menilai perilaku kurang. Hal itu dikarenakan pemimpin selalu memberikan bimbingan, arahan, komunikasi yang baik sesama perawat dan menghargai ide-ide dari bawahan.

\section{Kinerja Perawat Dalam \\ Penatalaksanaan Standar Praktik Professional Di Ruang Mawar Kelas II RSUD Asembagus Kab. Situbondo}

Data mengenai kinerja perawat pelaksana di ruang mawar kelas II RSUD Asembagus Kab. Situbondo berdasarkan data hasil penelitian didapatkan bahwa kinerja perawat hampir setengah kinerja perawat baik diantaranya sebanyak 8 responden $(40 \%)$ dan hampir setengah responden kinerja perawat cukup sebanyak 4 responden (20\%) dari 20 responden. Dan dari penilaian 2 responden $(10 \%)$ adalah kinerja baik pendidikan S1 keperawatan, 6 responden (30\%) pendidikan D3 keperawatan, 2 responden (10\%) kinerja perawat kurang pendidikan D3.

Dari hasil penelitian ini sebagian responden kinerja yang baik sekali berpendidikan S1 keperawatan yaitu sebagian kecil 1 responden (5\%), dan sebagian kecil lainnya responden kinerja baik berpendidikan S1 keperawatan yaitu 2 responden (10\%), dan sebagian kecil responden kinerja cukup yang berpendidikan D3 keperawatan yaitu 4 responden (20\%), dan sebagian kecil lainnya responden kinerja kurang berpendidikan D3 keperawatan yaitu 2 responden $(10 \%)$. Dalam penelitian ini didapatkan kinerja perawat yang baik sekali hal ini didapatkan banyak perawat dari S1 Keperawatan dan yang kinerja cukup dan kurang didapatkan dari D3 Keperawatan, hal ini sesuai dengan pendapat Gibson, dkk, (1997) didalam Nursalam (2013) bahwa faktor-faktor yang mempengaruhi perilaku dan kinerja adalah faktor individu (internal), meliputi: kemampuan, latar belakang, demografi, faktor organisasi (external), meliputi: sumber daya manusia, kepemimpinan, hal ini terlihat pada 
sebagian dari responden pada pernyataan kinerja perawat lembar observasi. Faktorfaktor yang mempengaruhi perilaku individu atau kinerja karyawan terdapat tiga faktor menurut (Gibson, dkk, 1997) didalam Nursalam (2013) diantaranya adalah faktor individu, faktor psikologi, dan faktor organisasi. Faktor pada kelompok individu merupakan faktor utama yang mempengaruhi perilaku kinerja, yaitu Kemampuan dan keterampilan, terdiri dari mental dan fisik, Latar belakang, terdiri dari keluarga, tingkat sosial, dan pengalaman. Demografis, terdiri dari umur, etnis, dan jenis kelamin. Menurut Notoadmojo (1992) dalam Nursalam (2013). Pendidikan memberikan pengetahuan yang langsung bukan saja yang langsung pelaksanaan tugas tetapi juga landasan untuk mengembangkan diri serta kemampuan memanfaatkan semua sarana yang ada di sekitar untuk kelancaran tugas (Nursalam, 2013).

Dengan hal ini pendidikan sangat berkaitan dengan kinerja seseorang, semakin tinggi tingkat pendidikan seseorang akan semakin tinggi pula tingkat kinerja yang efektif. Responden D3 Keperawatan merupakan perawat vokasi dan S1 Keperawatan merupakan perawat profesi yang seharusnya perawat S1 Keperawatan lebih banyak dan diharapkan produktifitas kerja perawat memberikan dampak positif kerja yang profesional namun tingkat kinerja juga akan dilihat seberapa disiplin mereka dalam melakukan tugas, mematuhi aturan yang berlaku dan penguasaan disiplin ilmu pengetahuan yang pernah mereka dapatkan.

\section{Hubungan gaya kepemimpinan demokratis kepala ruang dengan kinerja perawat dalam penatalaksanaan standar praktik professional di ruang mawar merah kelas II RSUD Asembagus Kab. Situbondo.}

Berdasarkan hasil penelitian diatas menunjukkan bahwa pada hasil analisa data responden dengan gaya kepemimpinan demokratis kepala ruang perilaku baik, perilaku cukup dan motivasi kerja perawat pelaksana kuat sebanyak 20 responden (100\%). Hasil analisa data hubungan gaya kepemimpinan demokratis kepala ruang dengan kinerja perawat pelaksana di RSUD Asembagus dengan menggunakan uji spearman rho diperoleh nilai $\rho$ Value $=$ $0,018<\alpha$ yang berarti H1 diterima yang artinya ada hubungan Gaya Kepemimpinan demokratis dengan kinerja perawat di ruang mawar kelas II RSUD Asembagus dengan nilai korelasi Spearman sebesar 525 menunjukkan bahwa arah korelasi negatif dengan kekuatan korelasi yang lemah.

Faktor-faktor gaya kepemimpinan demokrasi menururt Nugroho, A (2010) ada 4 (empat macam), yaitu: keputusan dibuat bersama antara pemimpin dan bawahan, terdapat suasana saling percaya, saling hormat, saling harga menghargai, pemimpin mendorong prestasi sempurna kepada bawahan dalam batas kemampuan secara wajar, Pujian dan kritik seimbang.

Hasil dari penelitian ini sesuai dengan pernyataan di atas bahwa hubungan gaya kepemimpinan kepala ruang dengan kinerja perawat pelaksana dibuktikan dengan 7 dari 20 responden (35\%) yang gaya kepemimpinan demokratis kepala ruang perilaku baik dengan kinerja yang baik dan 4 dari 20 responden (20\%) yang gaya kepemimpinan demokratis kepala 
ruang baik dengan kinerja cukup. Hal ini menunjukkan pemimpin yang perilaku baik, cukup, kurang mempengaruhi kinerja perawat pelaksana yang baik sekali, baik, cukup, kurang dan kurang sekali. Hal ini dapat diartikan bahwa gaya kepemimpinan demokratis kepala ruang sangat menentukan tingkat kinerja perawat. Sehingga dapat dikatakan semakin baik gaya kepemimpinan demokratis dalam bekerja akan semakin baik pula tingkat kinerja perawat, dan sebaliknya jika gaya kepemimpinan demokratis kurang maka akan semakin kurang tingkat kinerja perawat.

\section{SIMPULAN}

Ada hubungan antara gaya kepemimpinan demokratis dengan kinerja perawat penatalaksanaan standar praktik professional di ruang mawar merah kelas II RSUD Asembagus Kabupaten Situbondo, dengan sebagian besar mempunyai gaya kepemimpinan demokratis perilaku baik 13 (65\%) responden dan hampir setengah mempunyai kinerja baik sebanyak 8 (40\%) responden.

\section{SARAN}

Saran dalam penelitian ini adalah diperlukannya kepala ruangan untuk selalu meningkatkan gaya kepemimpinan baik dalam diri sendiri dan dari luar, sehingga kinerja yang baik diharapkan tetap dipertahankan dalam melaksanakan tanggung jawab kinerja oleh perawat, sehingga diharapkan akan dapat menimbulkan pelayanan yang baik serta membentuk citra yang baik bagi rumah sakit dimasyarakat.

\section{DAFTAR PUSTAKA}

1. Arikunto, S., 2009. Prosedur Penelitian Suatu PendeatanPraktik. Edisi Revisi 6. Jakarta: Rineka Cipta.

2. Arwani., Supriyatno, H. 2006. Manajemen Bangsal Keperawatan. Jakarta: EGC.

3. Bove, C. L. 1995. Management. New York: Mc Graw Hill Inc.Buchori Zainun.

4. Danim, Sudarwan. 2004. Motivasi Kepemimpinan dan Efektivitas Kepemimpinan. Jakarta: PT. Rineka Cipta.

5. Departemen Kesehatan RI. 2004. Keputusan Menteri Kesehatan Republik Indonesia, Jakarta: Kementerian Kesehatan Republik Indonesia.

6. Fahriadi. 2008. Determinan Kinerja Perawat Di Instalasi Rawat Inap Ratu Zalecha Martapura Kabupaten Banjar Kalimantan Selatan. Skripsi.

7. Fuadiputra, Iqbal Ramadhani, and Dodi Wirawan Irawanto. 2013. Pengaruh Gaya Kepemimpinan Demokratis Terhadap Kinerja Paramedis Di Rumah Sakit Al-Rohmah. Jurnal Ilmiah Mahasiswa FEB 2.2.

8. Gibson, J.L., Ivancevich, J.M., \& Donnelly Jr, J.M. 2006. Perilaku Organisasi, (Adiarni, N., Penerjemah). Jakarta: Binarupa Aksara.

9. Gillies, D.A. 1996. Manajemen keperawatan: Suatu pendekatan sistem. Alihbahasa D. Sukmana, dkk. (edisi kedua). WB Saunders Company.

10. Hersey \& Blanchard. 1992. Kepemimpinan dan Motivasi. Jakarta: PT Indeks Kelompok Gramedia.

11. Hotgetts dan Kuratko. 2004. Entrepreneurship (Theory, Process, Practice). USA : Thomson Learning. 
12. Huber, D.L. 2006. Leadership and nursing care management. 3th edition. Philadelphia: Elsevier.

13. Jerris, L. A. 1999. Human Resources Management for Hospitality. New Jersey: Prentice Hall.

14. Kartini Kartono. 2010. Pemimpin dan Kepemimpinan. Jakarta: PT. Raja Grafindo Persada.

15. Marquis, B.L., \& Huston, C.J. 2006. Leadership roles and management functions innursing theory and application. (5th Edition). Philadelphia: Lippincott Williams and Wilkins.

16. Notoatmodjo, S. 2012. Metodologi Penelitian Kesehatan. Jakarta: Rineka Cipta.

17. Nursalam. 2008. Konsep dan PenerapanMetodologi Penelitian Ilmu Keperawatan. Jilid 1. Jakarta: Salemba Medika.

18. 2009. Konsep dan Penerapan Metodologi Penelituan Ilmu Keperawatan Pedoman Skripsi, Tesisdan Instrumen Penelitian Keperawatan. Jakarta: Salemba Medika.

19._ 2010. Konsep dan penerapan metodologi penelitian ilmu keperawatan. Pendekatan Sistem). Jakarta. EGC.

20. 2012. Management Keperawatan edisi 3, Jakarta: Salemba Medika.

21. PPNI. 2006. Rancangan pedoman pengembangan sistem jenjang karir professional perawat. Jakarta: PPNI.

22. Potter, P.A., \& Perry, A.G. 2009. Fundamental Of Nursing E/7. Jakarta. Salemba Medika Elsevier Mosby.

23. Robbins, Stephen P dan Coulter, Mary. 2002. Manajemen, Edisi ketujuh, jilid 2, Terjemahan Sarwiji dan Hermaya.
Jakarta: PT Indeks Kelompok Gramedia.

24. Robbins, S.P. 2003. Perilaku organisasi. (jilid 1). (Tim Indeks, penerjemah).Jakarta:Indeks

25. Susatyo, H. 2012. Cara Mudah Memahami Manajemen Kesehatan Dan Rumah Sakit. Yogyakarta: Gosyen Publishing.

26. Sastrohadiwiryo, S. 2005. Manajemen Tenaga Kerja Indonesia Pendekatan Administrasi Dan Operasional. Jakarta: Bumi Aksara.

27. Sugiyono. 2010. Statistika Untuk Penelitian. Bandung: Alfabeta.

28. 2010 Metode Penelitian pendidikan Pendekatan Kuantitatif, Kualitatif, dan $R$ \& D. Bandung: Alfabeta.

29. Suza, S. 2008. Standar untuk praktek keperawatanhttp://library.usu.ac.id/do wnload/fk/keperawatan-dewi.pdf diunduh tgl 8 januari 2016 jam 11.55 WIB.

30. Tappen. 2004. Essentials nursing leadership and management, Philadelphia: F.A. Davis Company.

31. Timpe, A Dale. 2002. Seri MSDM, kinerja/performance, Cetakan Kelima, AlihBahasa Sofyan Cikmat. Jakarta: PT Gramedia Asri Media.

32. Wibowo. 2007. Manajemen kinerja. Jakarta: Raja Grafindo Persada.

33.___ 2013. Manajemen Kinerja E/3. Jakarta: Rajawali Pers.

Cite This Article As: Yulianto, Purwanto, N.H., Firmansyah, R.R. Hubungan Gaya Kepemimpinan Demokratis Dengan Kinerja Perawat Dalam Penatalaksanaan Standar Praktik Professional Di Ruang Mawar Merah Kelas II RSUD Asembagus Kabupaten Situbondo. Nurse and Health: Jurnal Keperawatan 2018; 7(1): 13-22. 